DOI: https://doi.org/10.24127/ajpm.v10i2.3641

\title{
PROSES BERPIKIR SPASIAL DITINJAU DARI KECERDASAN INTRAPERSONAL MAHASISWA PENDIDIKAN MATEMATIKA
}

\author{
Henry Suryo Bintoro ${ }^{*}$, Sumaji ${ }^{2}$ \\ ${ }^{1,2}$ Universitas Muria Kudus, Kudus, Indonesia \\ * Corresponding author. Hadipolo RT 2 RW 2 Jekulo, 59382, Kudus, Indonesia \\ E-mail: $\quad \underline{\text { henry.suryo@umk.ac.id }}^{\left.{ }^{*}\right)}$ \\ sumaji@umk.ac.id $^{2)}$
}

Received 26 March 2021; Received in revised form 19 June 2021; Accepted 05 July 2021

\begin{abstract}
Abstrak
Tujuan penelitian ini untuk mendeskripsikan proses berpikir spasial mahasiswa pada mata kuliah geometri ruang ditinjau dari kecerdasan intrapersonal. Penelitian ini merupakan jenis penelitian kualitatif deskriptif yang dilaksanakan di Program Studi Pendidikan Matematika Universitas Muria Kudus tahun akademik 2020/2021. Instrumen penelitian yang digunakan yaitu pedoman wawancara, dokumentasi, soal tes kemampuan spasial dan angket kecerdasan intrapersonal. Subjek penelitian terdiri 2 mahasiswa dengan kecerdasan intrapersonal tinggi dan 2 mahasiswa dengan kecerdasan intrapersonal sedang. Subjek penelitian diberikan tes kemampuan spasial kemudian dilakukan wawancara secara mendalam terkait proses berpikir spasial. Hasil penelitian dianalisis dengan triangulasi metode, yaitu hasil tes kemampuan spasial dan hasil wawancara dibandingkan dan dicek kembali derajat keyakinan seorang subjek untuk memperoleh keakuratan penemuan. Hasil penelitian menunjukkan ketercapaian kemampuan spasial pada tingkatan baik pada subjek yang memiliki kecerdasan intrapersonal tinggi maupun sedang. Hal tersebut dikarenakan mereka berpikir terarah dan fokus untuk mencapai tujuan, memiliki kepercayaan diri yang tinggi, banyak terlibat dalam kegiatan mandiri, memiliki sikap kemandirian yang tinggi, kesalahan masa lalu dijadikan pembelajaran untuk masa depan, belajar dan bekerja seorang diri dengan baik.
\end{abstract}

Kata kunci: Geometri; kecerdasan intrapersonal; kemampuan spasial.

\begin{abstract}
The purpose of this study was to describe students' spatial thinking processes in the spatial geometry course in terms of intrapersonal intelligence. This research is descriptive qualitative research conducted in the Mathematics Education Study Program of Muria Kudus University in the academic year 2020/2021. Innovative research instruments, interviews, documentation, spatial ability test questions, and intrapersonal intelligence questionnaires. The research subjects consisted of 2 students with high intrapersonal intelligence and 2 students with moderate intrapersonal intelligence. Research subjects were given, ability tests, then interviews, interviews, thinking, and spatial thinking. The results were analyzed using triangulation methods, namely the results of the spatial ability test and the results of the interviews were compared and checked again on the degree of confidence of an subjekt to obtain the accuracy of the findings. The results showed that the achievement of spatial abilities at a good level in subjects who had high or moderate intrapersonal intelligence. This is because they think directed and focused on achieving goals, have high self-confidence, many are involved in independent activities, have a high independent attitude, past mistakes are used as learning for the future, study and work well alone.
\end{abstract}

Keywords: Geometry; intrapersonal intelligence; spatial ability.

This is an open access article under the Creative Commons Attribution 4.0 International License 
DOI: https://doi.org/10.24127/ajpm.v10i2.3641

\section{PENDAHULUAN}

Salah satu materi pokok matematika yang sulit dipahami oleh mahasiswa adalah geometri. Geometri sebagai salah satu cabang matematika memiliki peran penting dalam pembelajaran matematika (Zuya \& Kwalat, 2015)(Zuliana et al., 2020). Sejalan dengan (Serin, 2018) bahwa geometri salah satu cabang penting dari Matematika, mendapat tempat dalam pendidikan untuk pengembangan pemikiran kritis dan pemecahan masalah, lebih jauh lagi, bahwa bentukbentuk geometri adalah bagian dari kehidupan kita karena muncul hampir di mana-mana, geometri digunakan juga dalam sains dan seni.

Materi geometri di perguruan tinggi, khususnya program studi Pendidikan Matematika menjadi sulit karena berisi penyajian abstraksi dari pengalaman visual dan spasial, misalnya bidang, pola, pengukuran dan pemetaan. Geometri menjadi sulit karena tingkat abstraksi geometri objek yang tinggi dan kemampuan visualisasi objek abstrak (kemampuan spasial) yang rendah. Sejalan dengan (Khusna \& Anissa, 2021)(Wicaksono et al., 2021) bahwa mahasiswa masih mengalami hambatan dalam menguasai konsep dan memecahkan masalah pada pembelajaran geometri. Mengembangkan pemikiran mahasiswa dan indra geometri adalah penting dan mereka akan membutuhkannya dengan memiliki pemahaman yang kuat tentang fakta-fakta dalam geometri (Ahamad et al., 2018).

Proses berpikir spasial diperlukan untuk menyelesaikan masalah geometri. Kemampuan berpikir dapat ditingkatkan dengan proses berpikir yang sistematik (Bintoro et al., 2021). Pentingnya mempelajari pemikiran spasial karena berhubungan dengan indikator kecepatan keberhasilan matematika (Tikhomirova, 2017). Penelitianpenelitian terkait berpikir spasial sudah banyak dilakukan. Penelitian (Kurniati et al., 2021) menunjukkan subyek dengan tipe gaya belajar visual dalam mengkonstruksi pengetahuan spasial baru didominasi oleh proses asismilasi. Penelitian (Murtafi'ah \& Masfingatin, 2015) menunjukkan mahasiswa dalam memahami masalah menggunakan proses berpikir asimilasi, dalam merencanakan pemecahan masalah menggunakan proses berpikir asimilasi dan akomodasi tetapi kurang sempurna. Penelitian (Seah \& Horne, 2020) menunjukkan bahwa penalaran spasial yang baik menunjukkan abstraksi yang terhubung dan terintegrasi yang mengarah pada keberhasilan dalam penalaran tentang konsep geometri.

Terjadinya permasalahan dalam memahami konsep geometri dimungkinkan juga dikarenakan perbedaan karakteristik individu atau perbedaan persepsi dalam memahami masalah, yaitu salah satunya perbedaan kecerdasan intrapersonal. Kecerdasan Intrapersonal adalah kecerdasan yang berhubungan dengan kesadaran dan pengetahuan tentang diri sendiri (Sholikhati et al., 2018). Kecerdasan intrapersonal merupakan pengetahuan diri dan kemampuan untuk bertindak secara adaptif atas dasar pengetahuan tersebut. Kecerdasan ini mencakup gambaran tentang kekuatan dan keterbatasan diri sendiri, kesadaran akan suasana hati, niat, motivasi, keinginan dan kapasitas untuk disiplin diri, pemahaman diri, dan harga diri (Gleason, 2011).

Kecerdasan intrapersonal membantu individu untuk membuat penilaian dan perbedaan antara pemikiran mereka sendiri, untuk membangun model mental yang sesuai dari diri mereka 
DOI: https://doi.org/10.24127/ajpm.v10i2.3641

sendiri dan mengandalkan model tersebut ketika membuat keputusan tentang kehidupan mereka sendiri. Memfasilitasi akses ke kehidupan batinnya, penting untuk mengenal diri sendiri, memungkinkan kesadaran diri, pemahaman diri, motivasi diri dan kontrol perilaku, emosi dan bentuk ekspresi sendiri (Perez \& Ruz, 2014). Kecerdasan intrapersonal membuat ikatan yang baik dengan orang lain dan menjadikan seseorang menguasai hasrat dan perasaan orang lain, serta kecerdasan intrapersonal mengakibatkan seseorang memiliki pengetahuan yang lebih baik tentang diri sendiri dan bisa membedakan perasaan mereka sendiri (Behjat, 2012).

Berdasarkan hasil-hasil penelitian sebelumnya belum ada teori yang membahas hubungan antara proses berpikir spasial dengan kecerdasan intrapersonal mahasiswa. Tujuan penelitian ini melaksanakan kajian lebih mendalam untuk memandang lebih rinci proses berpikir spasial mahasiswa dalam menyelesaikan masalah geometri ditinjau dari kecerdasan intrapersonal. Penemuan akar permasalahan dari kemampuan spasial mahasiswa pada masalah geometri berdasarkan kecerdasan intrapersonal memberikan kajian untuk merekomendasikan pembelajaran yang lebih terarah.

\section{METODE PENELITIAN}

Penelitian ini berjenis penelitian kualitatif diskriptif. Penelitian ini dilakukan di Program Studi Pendidikan Matematika Universitas Muria Kudus Semester III materi Geometri Ruang tahun akademik 2020/2021. Subjek penelitian ini adalah 27 mahasiswa. Pemilihan subjek didasarkan pada kriteria kecerdasan intrapersonal mahasiswa.
Tahapan penelitian diawali dengan memberikan angket kecerdasan intrapersonal pada seluruh mahasiswa yang berjumlah 27 orang untuk mengetahui kriterianya. Selanjutnya dilakukan tes kemampuan spasial dan dilanjutkan dengan wawancara mendalam. Memperhatikan variasi jawaban dan keunikan jawaban tes terpilih 2 mahasiswa dengan kecerdasan intrapersonal tinggi dan 2 mahasiswa dengan kecerdasan intrapersonal sedang. Kecerdasan intrapersonal rendah tidak terpilih karena tidak ada mahasiswa dengan kriteria rendah. Keempat subjek dilakukan wawancara mendalam untuk mengetahui proses berpikir spasial mahasiswa dihubungkan dengan hasil tes kemampuan spasialnya. Melalui kajian teori dan hasil analisis, ditemukan konsep rekomendasi pembelajaran terkait kemampuan spasial dilihat dari kecerdasan intrapersonalnya.

Instrumen utama penelitian adalah peneliti sendiri, dan instrumen pendukungnya adalah angket kecerdasan intrapersonal, soal tes kemampuan spasial dan pedoman wawancara. Angket kecerdasan intrapersonal mengacu pada indikator 1) kesadaran mengenali perasaan-perasaan diri sendiri, 2) keterampilan untuk mengungkapkan pikiran, perasaan, pendapat dan keyakinan, 3) penilaian diri yang tinggi, 4) mempunyai sikap kemandirian, 5) memaksimalkan potensi diri sendiri, 6) pengetahuan diri tentang tujuan-tujuan dan maksudmaksud pribadi, dan 7) pengetahuan diri akan nilai-nilai pribadi. Soal tes kemampuan spasial terdiri dari lima soal dan indikatornya yaitu, 1) persepsi keruangan, 2) visualisasi keruangan, 3) rotasi pikiran, 4) relasi keruangan, dan 5) orientasi keruangan. Pedoman wawancara digunakan untuk 
DOI: https://doi.org/10.24127/ajpm.v10i2.3641

mendapatkan informasi secara rinci tentang proses berpikir spasial berdasarkan indikator kemampuan spasial dan menghubungkan dengan hasil penyelesaian mahasiswa dalam memecahkan masalah geometri.

Teknik analisis data yang digunakan merujuk pada Miles dan Huberman (Sukestiyarno, 2020) yaitu reduksi data, penyajian data, dan penarikan kesimpulan. Hasil penelitian dianalisis dengan triangulasi metode, yaitu hasil tes kemampuan spasial dan hasil wawancara dibandingkan dan dicek kembali derajat keyakinan seorang subjek untuk memperoleh keakuratan penemuan.

\section{HASIL DAN PEMBAHASAN}

Berdasarkan hasil angket yang diberikan kepada semua mahasiswa, diperoleh bahwa dari 27 mahasiswa yang diberikan angket diperoleh 11 mahasiswa memiliki kriteria kecerdasan intrapersonal tinggi, 16 mahasiswa memiliki kecerdasan intrapersonal sedang dan 0 mahasiswa memiliki kecerdasan intrapersonal rendah. Fokus penelitian ini hanya memilih empat subjek penelitian. Selanjutnya dipilih 2 mahasiswa dari 11 mahasiswa yang memiliki kriteria kecerdasan intrapersonal tinggi dan 2 mahasiswa dari 16 mahasiswa yang memiliki kriteria kecerdasan intrapersonal sedang. Kecerdasan intrapersonal rendah tidak dipilih karena dari awal menunjukkan tidak ada mahasiswa dengan kriteria kecerdasan intrapersonal rendah.

Subjek yang terpilih, kemudian diberikan tes kemampuan spasial dengan materi kedudukan titik, garis, dan bidang. Menurut Maier dalam (Permatasari et al., 2018) indikator kemampuan spasial dalam penelitian ini dapat dilihat pada Tabel 1.
Tabel 1. Indikator kemampuan spasial

\begin{tabular}{|c|c|c|}
\hline No & $\begin{array}{c}\text { Aspek } \\
\text { kemampuan } \\
\text { spasial }\end{array}$ & Indikator \\
\hline 1 & $\begin{array}{l}\text { Persepsi } \\
\text { keruangan }\end{array}$ & $\begin{array}{lr}\text { Mampu } & \text { menjelaskan } \\
\text { wujud ataupun } \\
\text { dimensi yang } \\
\text { sesungguhnya dari } \\
\text { sesuatu tampilan } \\
\text { dimensi tiga yang } \\
\text { bersumber pada } \\
\text { perpektif tertentu }\end{array}$ \\
\hline 2 & $\begin{array}{l}\text { Visualisasi } \\
\text { keruangan }\end{array}$ & $\begin{array}{lr}\text { Mampu menjelaskan } \\
\text { keadaan ataupun } \\
\text { wujud r yang } \\
\text { sesungguhnya dari } \\
\text { sesuatu pergantian } \\
\text { lapisan ataupun } \\
\text { bagian tertentu objek }\end{array}$ \\
\hline 3 & $\begin{array}{l}\text { Rotasi } \\
\text { pikiran }\end{array}$ & $\begin{array}{l}\text { Mampu menjelaskan } \\
\text { posisi atau bentuk } \\
\text { bangun ruang yang } \\
\text { diputar }\end{array}$ \\
\hline 4 & $\begin{array}{l}\text { Relasi } \\
\text { keruangan }\end{array}$ & $\begin{array}{l}\text { Mampu menjelaskan } \\
\text { kaitan elemen- } \\
\text { elemen pada dimensi } \\
\text { tiga }\end{array}$ \\
\hline 5 & $\begin{array}{l}\text { Orientasi } \\
\text { keruangan }\end{array}$ & \begin{tabular}{lr}
\multicolumn{3}{l}{ Mampu menjelaskan } \\
wujud suatu objek \\
jika dilihat dari \\
berbagai & sudut \\
pandang & dan \\
kedudukan tertentu
\end{tabular} \\
\hline
\end{tabular}

Berdasarkan Tabel 1 penelitian ini menganalisis lima aspek kemampuan spasial yaitu (1) persepsi keruangan yaitu kemampuan untuk mengamati posisi suatu benda secara vertikal atau horizontal, (2) visualisasi keruangan adalah kemampuan untuk menampilkan perubahan atau aturan perpindahan suatu bentuk dari tiga dimensi ke dua dimensi atau sebaliknya, (3) rotasi pikiran adalah kemampuan memutar benda dua dimensi dan tiga dimensi secara akurat, (4) relasi keruangan yaitu kemampuan memahami susunan benda, bagian-bagiannya dan hubungannya, dan (5) orientasi keruangan adalah 
kemampuan mengamati objek dalam berbagai situasi.

Dari hasil penelitian dengan menggunakan triangulasi metode yaitu melalui perbandingan dan pengecekan kepercayaan subjek diperoleh dengan cara membandingkan hasil tes tertulis dengan hasil wawancara. Setelah menganalisis data tingkat kemampuan spasial dari hasil tes kemampuan spasial, data wawancara dan data hasil triangulasi masing-masing subjek, data yang diperoleh dibagi menjadi dua kelompok yaitu siswa dengan kecerdasan intrapersonal tinggi dan kecerdasan intrapersonal sedang. Berikut Tabel 2 yang merupakan hasil analisis kemampuan spasial mahasiswa dengan kecerdasan intrapersonal tinggi. Subjek terdiri dari 2 mahasiswa, yaitu subjek MKN dan subjek NMP.

Tabel 2. Hasil analisis kemampuan spasial mahasiswa kecerdasan intrapersonal tinggi

\begin{tabular}{clccc}
\hline \multirow{2}{*}{ No } & Indikator & $\begin{array}{c}\text { Skor } \\
\text { Maks }\end{array}$ & \multicolumn{2}{c}{ Skor Subjek } \\
\cline { 4 - 5 } & MKN & NMP \\
\hline 1 & $\begin{array}{l}\text { Persepsi } \\
\text { Keruangan }\end{array}$ & 4 & 3 & 4 \\
2 & $\begin{array}{l}\text { Visualisasi } \\
\text { Keruangan }\end{array}$ & 3 & 2 & 2 \\
3 & $\begin{array}{l}\text { Rotasi } \\
\text { Pikiran }\end{array}$ & 3 & 1 & 3 \\
4 & $\begin{array}{l}\text { Relasi } \\
\text { Keruangan }\end{array}$ & 2 & 1 & 2 \\
5 & $\begin{array}{l}\text { Orientasi } \\
\text { Keruangan }\end{array}$ & 4 & 4 & 2 \\
\hline
\end{tabular}

Berdasarkan Tabel 2, terlihat bahwa skor maksimal dicapai pada aspek persepsi keruangan dan orientasi keruangan. Sedangan aspek visualisasi keruangan, rotasi pikiran dan relasi keruangan belum maksimal. Berikut penjelasan pada masing-masing indikator kemampuan spasial.

Pada aspek persepsi keruangan, mahasiswa harus dapat menyatakan ukuran atau bentuk sebenarnya dari tampilan dimensi tiga berdasarkan sudut pandang tertentu. Pada aspek ini subjek NMP lebih baik daripada subjek MKN. Perbedaannnya hanya pada kesimpulan saja. Subjek MKN memberikan jawaban panjang diagonal ruang 3 kasus dengan benar akan tetapi dalam penyimpulannya masih salah. Artinya sebenarnya subjek MKN mampu menyelsaikan semua kasus dengan benar, hanya di saat penyimpulan subjek MKN kurang teliti. Sementara untuk subjek NMP memberikan jawaban panjang diagonal ruang 3 kasus dengan benar dan dapat menyimpulkan dengan benar mengenai kasus yang memiliki panjang diagonal yang sama. Pada aspek ini kedua subjek mampu mencapai indikator yang diharapkan yaitu dapat menyatakan ukuran atau bentuk sebenarnya dari tampilan dimensi tiga berdasarkan sudut pandang tertentu, hanya ada sedikit kekurangtelitian di akhir penyimpulan untuk subjek MKN.

Pada aspek visualisasi keruangan, mahasiswa harus mampu menyatakan situasi atau bentuk sebenarnya dari tatanan atau perubahan sebagian dari benda tertentu. Subjek MKN mampu menggambarkan sketsa kubus ABCD.EFGH dengan benar dan memberikan jawaban benar mengenai jarak garis ke garis, akan tetapi masih salah dalam menentukan jarak garis ke bidang. Sedangkan subjek NMP mampu memberikan jawaban benar mengenai jarak garis ke garis dan jarak garis ke bidang, akan tetapi dalam pengerjaannya belum menggambarkan sketsanya. Subjek NMP sebenarnya mampu menggambar sketsanya, hanya dia kurang teliti dalam membaca soal. Pada aspek ini kedua subjek belum maksimal dalam mencapai indikator yang diharapkan yaitu mahasiswa mampu 
DOI: https://doi.org/10.24127/ajpm.v10i2.3641

menyatakan situasi atau bentuk sebenarnya dari tatanan atau perubahan sebagian dari benda tertentu, karena masih ada subjek yang belum memahami konsep jarak garis ke bidang dan kekurangtelitian dalam membaca soal.

Pada aspek rotasi pikiran, mahasiswa harus mampu menyatakan bentuk yang diputar atau posisi dari bentuk tersebut. Subjek MKN mampu menggambarkan sketsa kado yang telah diputar tetapi memberikan jawaban salah mengenai jarak titik ke bidang. Subjek MKN belum mampu menentukan garis yang merupakan jarak titik ke bidang. Subjek NMP mampu menggambarkan sketsa kado yang telah diputar dan memberikan jawaban benar mengenai jarak titik ke bidang. Subjek NMP dapat menyelesaikan permasalahan dengan lengkap dan benar. Pada aspek ini satu subjek sudah maksimal mencapai indikator, tetapi satu subjek belum maksimal mencapai indikator. Kedua subjek dapat menyatakan bentuk yang diputar atau posisi dari bentuk tersebut, meskipun ada satu subjek yang belum bisa menentukan letak garis dari jarak antara titik ke bidang.

Pada aspek relasi keruangan, mahasiswa harus mampu menyatakan keterkaitan bagian-bagian pada dimensi tiga yaitu kaitan antara titik, garis, dan bidang. Subjek MKN tidak mampu memberikan jawaban jarak titik ke garis dengan benar akan tetapi dapat menyimpulkan nilai kebenaran dari pernyataan yang diberikan secara benar. Subjek MKN mampu membayangkan hal tersebut, namun belum bisa menentukan dengan tepat hasil dari jarak titik ke garis pada kedua kasus tersebut. Pada subjek NMP mampu memberikan jawaban jarak titik ke garis dengan benar pada kasus 1 dan kasus 2 serta dapat menyimpulkan nilai kebenaran dari pernyataan yang diberikan secara benar. Subjek NMP dapat menyelesaikan permasalahan dengan lengkap dan benar. Pada aspek ini satu subjek sudah maksimal mencapai indikator, tetapi satu subjek belum maksimal mencapai indikator. Pada kenyataannya kedua subjek mampu menyatakan keterkaitan bagianbagian pada dimensi tiga yaitu kaitan antara titik, garis, dan bidang, akan tetapi satu subjek belum dapat merepresentasikannya ke dalam bentuk matematis, masih sebatas membayangkan objeknya.

Pada aspek orientasi keruangan, mahasiswa harus mampu menjelaskan bentuk bend ajika dilihat dari berbagai situasi dan sudut pandang tertentu. Subjek MKN mampu menggambarkan sketa pada kasus ayah dan pada kasus Rudi serta memberikan jawaban benar mengenai jarak bidang ke bidang pada kasus ayah dan kasus Rudi serta dapat menyimpulkan jarak triplek abu-abu ke triplek hitam pada kasus manakah yang lebih pendek dengan benar. Sedangkan subjek NMP belum mampu menggambarkan sketa pada kasus ayah dan pada kasus Rudi tetapi memberikan jawaban benar mengenai jarak bidang ke bidang pada kasus ayah dan kasus Rudi serta dapat menyimpulkan jarak triplek abu-abu ke triplek hitam pada kasus manakah yang lebih pendek dengan benar. Pada subjek NMP sebenarnya mampu menggambar sketsa tersebut, namun dia tidak menggambarkannya di lembar jawab. Artinya pada aspek ini kedua subjek sudah maksimal mencapai indikator yang diharapkan yaitu mampu menjelaskan bentuk bend ajika dilihat dari berbagai situasi dan sudut pandang tertentu, akan tetapi satu subjek belum 
menuliskan secara lengkap pada lembar jawab.

Berdasarkan hasil tes kemampuan spasial dan wawancara diperoleh subjek MKN mampu mencapai semua indikator kemampuan spasial. Pekerjaan tertulis dari MKN menunjukkan hasil yang belum maksimal, namun setelah dikonfirmasi MKN sebenarnya MKN paham dan mampu menyelesaikan soal yang diberikan, hanya saja kekurangtelitian dari MKN. Secara umum subjek MKN dapat menggambar sketsa dengan benar. Subjek MKN mampu merepresentasikan soal ke dalan bentuk gambar bangun ruang dengan tepat. Beberapa soal dijawab $\mathrm{MKN}$ hanya dengan membayangkan, dia tidak menuliskan jawaban secara lengkap sehingga penilaian secara tertulisnya menjadi tidak maksimal. Kecerdasan intrapersonal mempengaruhi kemampuan spasial mahasiswa. Kecerdasan intrapersonal berhubungan dengan kesadaran dan pengetahuan diri sendiri serta melibatkan kemampuan untuk secara akurat dan realistis menciptakan gambaran mengenai diri sendiri. Sejalan dengan hasil penelitian (Jayaseely, 2020) seseorang dengan kecerdasan intrapersonal tinggi mampu memahami diri sendiri, memotivasi diri sendiri, mencari solusi yang efisien dan menggunakan solusi untuk menyelesaikan permasalahan. Hal tersebut juga diperkuat hasil penelitian (Hajhashemi et al., 2018) bahwa kecerdasan intrapersonal dalam diri ini terletak pada pemahaman dan kesadaran individu akan perasaan dan pikirannya sendiri, sehingga kecerdasan intrapersonal yang tinggi mampu membentuk model diri yang akurat dan dapat menggunakan model tersebut untuk menyelesaikan permasalahan. Salah satu pekerjaan MKN dapat dilihat pada Gambar 1.

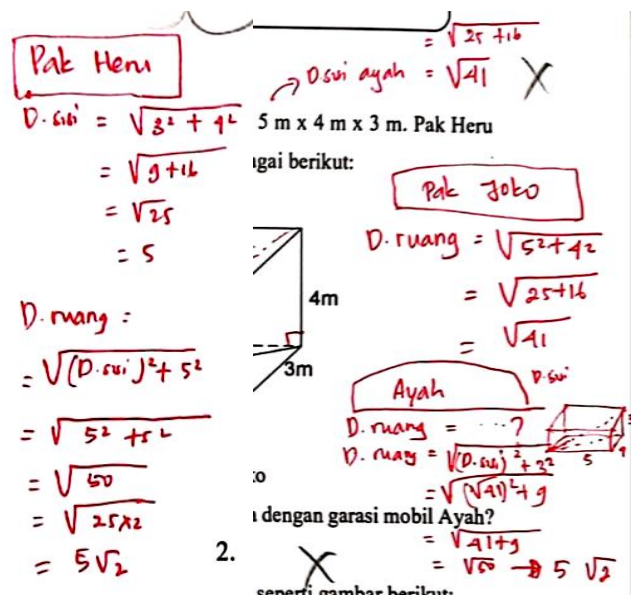

Gambar 1. Hasil pekerjaan aspek persepsi keruangan

Berdasarkan Gambar 1 menunjukkan bahwa subjek MKN mampu memberikan jawaban panjang diagonal ruang 3 kasus dengan benar namun memberikan kesimpulan yang salah mengenai kasus yang memiliki panjang diagonal yang sama. Subjek MKN hanya kurang teliti dalam membuat kesimpulan, padahal dengan jelas 3 kasus sudah dijawab dengan tepat. Hasil wawancara menunjukkan bahwa memang MKN sebenarnya mampu membuat kesimpulan, tetapi kurang teliti dalam menuliskannya. Hal tersebut menunjukkan MKN dapat mengamati suatu bangun ruang atau bagian-bagian bangun ruang yang diletakkan posisi horizontal atau vertikal.

Sujek kedua adalah NMP. Hasil tes tertulis kemampuan spasial NMP lebih baik dari MKN. Subjek NMP hampir semua soal dapat diselesaikan dengan lengkap dan benar. Semua soal perhitungan dapat dikerjakan secara matematis dengan tepat. Artinya subjek NMP menguasai konsep kedudukan titik, garis dan bidang dengan baik. Kekurangan NMP pada kelengkapan menjawab soal. Subjek NMP tidak menyertakan sketsa gambar untuk beberapa pertanyaan, padahal dalam soal menuntut untuk menggambar 
DOI: https://doi.org/10.24127/ajpm.v10i2.3641

sketsanya. Meskipun sketsa tidak digambar tetapi semua jawaban NMP benar. Akibatnya nilai NMP menjadi kurang maksimal. Subjek NMP juga masuk dalam kecerdasan intrapersonal tinggi, artinya subjek NMP mampu mengelola diri sendiri sehingga dapat menyelesaikan permasalahan dengan solusi pengala-man yang telah diperoleh pada pembelajaran sebelumnya. Dengan memiliki kecerdasan intrapersonal seseorang dapat mengoptimalkan kecerdasan lainnya seperti kecerdasan matematika dan kecerdasan visual spasial, artinya kecerdasan intrapersonal salah satu kecerdasan terpenting yang dapat dikembangkan karena mampu memaksimalkan kemampuannya (Prisani, 2017). Kecerdasan intrapersonal dibentuk dari perasaan, motivasi, kelemahan, kekuatan dan semua tentang diri mereka sendiri. Artinya apabila sesorang memahami kemampuan mereka sendiri, mereka akan lebih kreatif dan memecahkan persoalan (Simpuruh, 2020). Salah satu pekerjaan NMP dapat dilihat pada Gambar 2.

$$
\begin{aligned}
& \text { - wamua uenar! lengkapi dengan alasan! benar karem u keqw = TV } \\
& \text { lebih panjang daripada jarak V ke garis SQ" } 4 \text { Ke } \text { iw }^{2} \\
& \text { di: V k garis } S Q=\sqrt{(30 \sqrt{2})^{2}-(15 \sqrt{2})^{2}} \\
& =\sqrt{1800-450} \\
& =\sqrt{850}=15 \sqrt{6} \text { (jadi, jarak titit v } \\
& \text { Tentukan jarak titik T ke bidang PQVW! Ke gans Tw lebjik } \\
& \text { thlk TKE PQWW }=\frac{1}{2} \cdot T s \\
& =\frac{1}{2} \cdot 30 \sqrt{2} \\
& =15 . \sqrt{2} \mathrm{~cm} \text {. }
\end{aligned}
$$

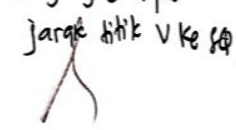

Gambar 2. Hasil pekerjaan aspek relasi keruangan dan rotasi pikiran

Berdasarkan Gambar 2, menunjukkan bahwa subjek NMP mampu memberikan jawaban jarak titik ke garis dengan benar pada kasus 1 dan kasus 2 serta dapat menyimpulkan nilai kebenaran dari pernyataan yang diberikan secara benar. Subjek NMP juga mampu menggambarkan sketsa kado yang telah diputar dan memberikan jawaban benar mengenai jarak titik ke bidang. Artinya NMP mampu merepresentasikan soal ke dalam sketsa gambar, kemudian dapat menunjukkan letak soal yang diminta serta dapat menghitung persoalan yang diminta. Subjek NMP dalam hal ini mampu merotasikan suatu bangun ruang secara tepat dan mampu memahami suatu objek atau bentuk spasial suatu objek dan keterkaitan antara satu bagian dengan bagian lainnya.

Selanjutnya yaitu hasil analisis

\begin{tabular}{|c|c|c|c|c|}
\hline \multirow{2}{*}{ No } & \multirow{2}{*}{ Indikator } & \multirow{2}{*}{$\begin{array}{l}\text { Skor } \\
\text { Maks }\end{array}$} & \multicolumn{2}{|c|}{ Subjek } \\
\hline & & & MD & MSR \\
\hline 1 & $\begin{array}{l}\text { Persepsi } \\
\text { Keruangan }\end{array}$ & 4 & 2 & 3 \\
\hline 2 & $\begin{array}{l}\text { Visualisasi } \\
\text { Keruangan }\end{array}$ & 3 & 2 & 2 \\
\hline 3 & $\begin{array}{l}\text { Rotasi } \\
\text { Pikiran }\end{array}$ & 3 & 1 & 1 \\
\hline 4 & $\begin{array}{l}\text { Relasi } \\
\text { Keruangan }\end{array}$ & 2 & 1 & 2 \\
\hline 5 & $\begin{array}{l}\text { Orientasi } \\
\text { Keruangan }\end{array}$ & 4 & 4 & 2 \\
\hline $\begin{array}{l}\text { me } \\
\text { ma } \\
\text { ker } \\
\text { me } \\
\text { bel } \\
\text { pac } \\
\text { ker }\end{array}$ & $\begin{array}{l}\text { Berdasark } \\
\text { unjukkan } \\
\text { ing subjel } \\
\text { ampuan s } \\
\text { unjukkan } \\
\text { m maksim } \\
\text { ampuan spa } \\
\text { ampuan }\end{array}$ & $\begin{array}{l}\text { ahwa } \\
\text { pada } \\
\text { sial. } \\
\text { da seti } \\
\text {. Beri } \\
\text {-masing } \\
\text { al. }\end{array}$ & $\begin{array}{l}\text { Tabel } \\
\text { skor } \\
\text { setiap } \\
\text { Hasil } \\
\text { p asp } \\
\text { it pe }\end{array}$ & $\begin{array}{r}3 \\
\text { nasing- } \\
\text { aspek } \\
\text { ersebut } \\
\text { k skor } \\
\text { jelasan } \\
\text { dikator }\end{array}$ \\
\hline
\end{tabular}
kemampuan spasial mahasiswa dengan kecerdasan intrapersonal sedang. Subjek terdiri dari 2 mahasiswa, yaitu subjek MD dan subjek MSR.Hasil tersebut dapat dilihat pada Tabel 3.

Tabel 3. Hasil analisis kemampuan spasial mahasiswa kecerdasan intrapersonal sedang 
DOI: https://doi.org/10.24127/ajpm.v10i2.3641

Pada aspek persepsi keruangan, mahasiswa harus dapat menyatakan ukuran atau bentuk sebenarnya dari tampilan dimensi tiga berdasarkan sudut pandang tertentu. Pada aspek ini subjek MD mampu memberikan kesimpulan yang benar mengenai kasus yang memiliki panjang diagonal yang sama, tetapi tidak memberikan penjelasan jawaban panjang diagonal ruang 3 kasus. Subjek MD hanya menalar secara deskriptif dan hasilnya tetapt, akan tetapi untuk penilaian masih belum maksimal. Untuk subjek MSR hasilnya berbanding terbalik dengan subjek MD, di mana subjek MSR memberikan jawaban panjang diagonal ruang 3 kasus dengan benar dan lengkap. Subjek MSR hanya salah dalam pemberian kesimpulan, padahal sudah bisa dilihat jawabannya dari hasil perhitungan. Subjek MSR kurang teliti dalam melihat kembali jawaban yang sudah ditulis untuk membuat kesimpulan. Hasil dari kedua subjek menunjukkan bahwa mereka sebenarnya paham dan mampu mengerjakan pada aspek ini, tetapi hanya kurang ketelitian yang menyebabkan skor tidak maksimal.

Pada aspek visualisasi keruangan, mahasiswa harus mampu menyatakan situasi atau bentuk sebenarnya dari tatanan atau perubahan sebagian dari benda tertentu. Subjek MD mampu menggambarkan sketsa kubus ABCD.EFGH dengan benar dan memberikan jawaban benar mengenai jarak garis ke bidang serta salah dalam memberikan jawaban mengenai jarak garis ke garis. Subjek MD sebenarnya sudah tepat dalam menentukan jarak garis ke garis, hanya saja dia salah dalam melakukan perhitungan. Hasil subjek MSR berbading terbalik dengan subjek MD. Subjek MSR mampu menggambarkan sketsa kubus ABCD.EFGH dengan benar dan memberikan jawaban benar mengenai jarak garis ke garis serta salah dalam memberikan jawaban mengenai jarak garis ke bidang. Subjek MSR sudah tepat dalam menentukan letak jarak garis ke bidang, tetapi salah dalam melakukan perhitungan. Hasil dari kedua subjek menunjukkan bahwa mereka sebenarnya paham dan mampu mengerjakan pada aspek ini, tetapi hanya kurang ketelitian yang menyebabkan skor tidak maksimal.

Pada aspek rotasi pikiran, mahasiswa harus mampu menyatakan bentuk yang diputar atau posisi dari bentuk tersebut. Subjek MD dan MSR mampu menggambarkan sketsa kado yang telah diputar tetapi tidak tepat dalam menghitung jarak titik ke bidang. Keduanya menguraikan dengan lengkap dan urut, tetapi hasilnya belum tepat.

Pada aspek relasi keruangan, mahasiswa harus mampu menyatakan keterkaitan bagian-bagian pada dimensi tiga yaitu kaitan antara titik, garis, dan bidang. Subjek MD mampu Memberikan jawaban jarak titik ke garis dengan benar pada satu kasus saja, sedangkan subjek MSR mampu Memberikan jawaban jarak titik ke garis dengan benar pada dua kasus saja. Kedua subjek tidak ada yang menyelesaikan soal dengan sempurna, yaitu menyelesaikan dengan benar pada tiga kasus. Subjek MD memberikan kesimpulan dengan benar tetapi proses perhitungan tidak lengkap, sedangkan subjek MSR menuliskan proses perhitungan dengan lengkap, namun dibagian kesimpulan masih menunjukkan kesalahan.

Pada aspek orientasi keruangan, mahasiswa harus mampu menjelaskan bentuk bend ajika dilihat dari berbagai situasi dan sudut pandang tertentu. Subjek MD mampu menggambarkan sketa pada kasus ayah dan pada kasus 
DOI: https://doi.org/10.24127/ajpm.v10i2.3641

Rudi serta memberikan jawaban benar mengenai jarak bidang ke bidang pada kasus ayah dan kasus Rudi serta dapat menyimpulkan jarak triplek abu-abu ke triplek hitam pada kasus manakah yang lebih pendek dengan benar. Subjek MD menjawab dengan sempurna pada aspek ini. Sedangkan subjek MSR mampu menggambarkan sketa pada kasus ayah dan memberikan jawaban benar mengenai jarak bidang ke bidang pada kasus ayah. Pada kasus Rudi, subjek MSR menjawab dengan kurang tepat sehingga salah dalam menyimpulkan jarak triplek abu-abu ke triplek hitam pada kasus manakah yang lebih pendek. Subjek MSR menjawab dengan lengkap dan urut, tetapi kurang teliti dalam menyusun sketsa gambar dari persoalan yang diberikan.

Berdasarkan hasil tes kemampuan spasial dan wawancara diperoleh subjek MD mampu mencapai semua indikator kemampuan spasial. Subjek MD sebenarnya mampu dalam mengerjakan semua soal tes kemampuan spasial. Subjek MD hanya kurang teliti dalam beberapa soal. Hasil wawancara mendalam menunjukkan subjek MD paham akan soal yang diberikan, hanya terkadang subjek MD menjawab soal dengan penalaran tanpa menuliskan secara lengkap hasilnya, sehingga menyebabkan hasilnya kurang maksimal. Subjek MD termasuk dalam kategori kecerdasan intrapersonal sedang. Subjek MD mampu memahami kemampuan dirinya sendiri dan apabila mengalami kesulitan, subjek MD berusaha mencari solusi dari pengalaman sebelumnya. Kecerdasan intrapersonal mempengaruhi kemampuan seseorang, khusunya kemampuan spasial. Sejalan dengan (Abdi \& Desfandi, 2020), bahwa terdapat hubungan yang signifikan antara kecerdasan spasial dan kecerdasan intrapersonal dengan hasil belajar. Kemampuan spasial dibentuk berdasarkan pemahaman masalah melalui indera, terutama ketika mata muncul dalam bentuk ruang, kemudian bentuk-bentuk geometris yang dipelajari yang ditangkap oleh mata diubah menjadi bentuk sketsa lainnya. Sedangkan pembentukan kecerdasan interpersonal adalah kemampuan memahami diri sendiri, dan bertindak sesuai dengan kekuatan dan keterbatasan seseorang, emosi, niat, motivasi, keinginan, disiplin diri, dan kemampuan memahami dan menghargai diri sendiri (Setyaningrum \& Siswantari, 2020). Salah satu pekerjaan MD dapat dilihat pada Gambar 3.

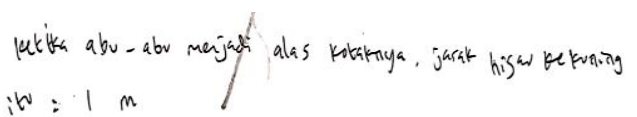

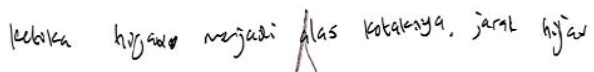

$$
\begin{aligned}
& \text { be waing: } 75 \mathrm{~cm} /
\end{aligned}
$$

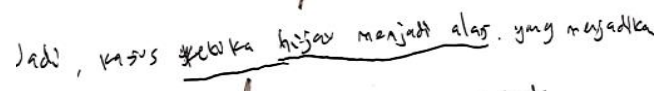

$$
\begin{aligned}
& \text { jarake nijo ke kughing lectik pendek daripada }
\end{aligned}
$$

Gambar 3. Hasil pekerjaan aspek orientasi keruangan

Berdasarkan Gambar 3, menunjukkan bahwa subjek MD mampu menggambar bentuk tumpukan kubus dari gambar di atas bila dilihat dari sisi belakang dengan benar. Subjek MD mampu menyelesaikan kasus dengan lengkap dan benar. Hal tersebut menunjukkan subjek MD mampu mencari pedoman fisik atau mental di dalam ruang atau penyesuaian dengan seseorang dalam situasi ruang khusus.

Subjek kedua adalah MSR. Hasil tes tertulis kemampuan spasial subjek MSR ditulis secara detail, lengkap dan runtut, tetapi masih ada beberapa jawaban belum sempurna. Subjek MSR 
kurang teliti dalam menyimpulkan, padahal semsedang seperti subjek MD. Artinya kecerdasan spasial juga berhubungan dengan kemampuan spasial seseorang. Kecerdasan intrapersonal yang baik dapat membuat seseorang memahami kemampuan diri sendiri, sehingga dia akan berupaya untuk menyelesaikan permasalahan dengan maksimal. Sejalan dengan (Murni \& Ruqoyyah, 2020), bahwa kecerdasan intrapersonal adalah kemampuan memahami diri sendiri dari tujuan, keinginan, dan sistem emosi yang terlihat jelas dalam pekerjaan. Hal tersebut diperkuat (Bintoro \& Zuliana, 2015) bahwa kecerdasan intrapersonal yang baik berpengaruh terhadap hasil belajar matematika. Dari hasil wawancara, memang benar sebenarnya subjek MSR mampu mengerjakan, hanya dia kurang cermat dalam membaca soal, sehingga salah dalam membuat kesimpulan. Subjek MSR termasuk subjek yang dalam pengerjaannya selalu lengkap dan runtut. Subjek MSR mengerjakan soal secara sistematis dan jelas. Subjek MSR juga memiliki kecerdasan intrapersonal kategori matematika, salah satunya kemampuan spasial (Mulbar et al., 2019). Salah satu pekerjaan MSR dapat dilihat pada Gambar 4.

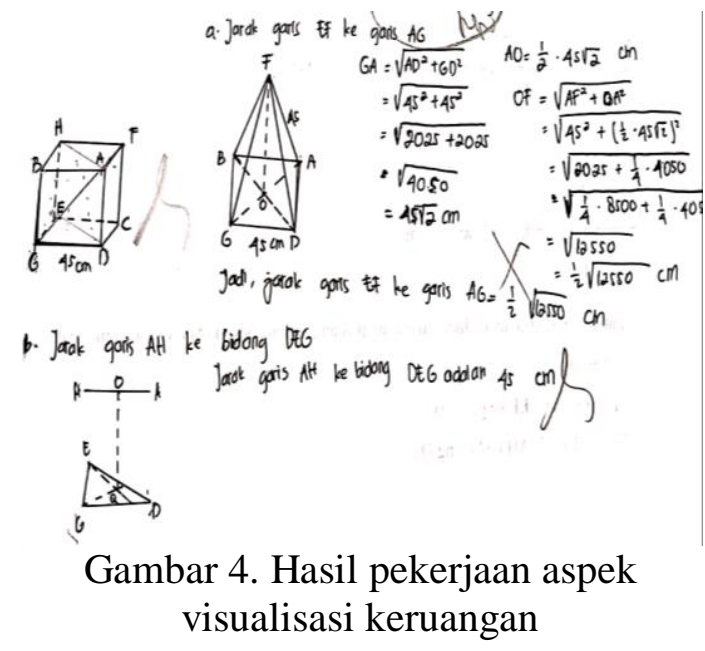

Berdasarkan Gambar 4, subjek MSR mampu menjelaskan kondisi atau bentuk sebenarnya dari pengaturan atau perubahan sebagian dari objek tertentu. Secara khusus subjek MSR mampu membuat sketsa dengan benar, mampu menentukan jarak garis ke garis dan jarak dari garis ke bidang. Subjek MSR hanya kurang teliti dalam melakukan perhitungan dan hal tersebut hanya terjadi pada penentuan jarak garis ke garis. Setelah dikonfirmasi melalui wawancara ternyata subjek MSR sebenarnya mampu mengerjakan, hanya karena ingin cepat selesai maka subjek MSR tidak melakukan pengecekan kembali. Hal tersebut menunjukkan subjek MSR mampu membayangkan atau memberikan gambaran umum tentang bentuk ruang tertentu, bagaimana bagian darinya berubah atau bergeser.

Berdasarkan hasil analisis keempat subjek diperoleh deskripsi proses berpikir spasial mahasiswa dengan kecerdasan intrapersonal tinggi dan sedang secara umum yaitu 1) mempunyai rasa percaya diri yang baik dalam belajar dan bekerja, 2) mempunyai pandangan hidup yang lebih baik, 3) mampu menganalisis diri, 4) memperlihatkan kemampuan yang kuat, 5) bersifat realitis terhadap diri sendiri (kelebihan dan kelemahan), 6) memperhatikan emosi mereka, 7) menemukan cara untuk mengungkapkan ide-idenya, 8) membangun model diri yang akurat, 9) memotivasi mereka untuk mengidentifikasi dan menemukan tujuan mereka, 10) membangun sistem nilai yang baik, 11) bekerja secara mandiri; 12) Ingin tahu tentang masalah dan mencoba menyelesaikannya; 13) mencoba menemukan dan memahami pengalaman masalah itu sendiri; 14) memahami kompleksitas diri Anda; 15) bertanggung jawab tinggi. 
DOI: https://doi.org/10.24127/ajpm.v10i2.3641

Secara keseluruhan hasil temuan menunjukkan ketercapaian kemampuan spasial pada tingkatan baik pada subjek yang memiliki kecerdasan intrapersonal tinggi maupun sedang. Hal tersebut dikarenakan mereka berpikir terarah dan fokus untuk mencapai tujuan, memiliki kepercayaan diri yang tinggi, banyak terlibat dalam kegiatan mandiri, memiliki sikap kemandirian yang tinggi, kesalahan masa lalu dijadikan pembelajaran untuk masa depan, belajar dan bekerja seorang diri dengan baik. Sejalan dengan (Bintoro \& Zuliana, 2015) kecerdasan intrapersonal yang baik berpengaruh terhadap prestasi belajar. Menurut (Sholikhati et al., 2018) kecerdasan intrapersonal tinggi dapat mencapai tingkat berpikir menganalisis dan subjek dengan kecerdasan intrapersonal sedang mampu mencapai tingkat menerapkan berpikir. Hal tersebut juga diperkuat (Perez \& Ruz, 2014) bahwa kecerdasan intrapersonal membantu mahasiswa untuk mengenal dirinya sendiri sehingga mereka mampu mengembangkan pengetahuan dengan baik.

Berdasarkan temuan penelitian, rekomendasi yang dapat diberikan adalah pendidik diharapkan mampu mengembangkan dan menggunakan metode pembelajaran yang dapat mengasah berbagai jenis kecerdasan yang dimiliki siswa sehingga dapat memberikan pengaruh terhadap peningkatan hasil belajar (Abdi \& Desfandi, 2020). Pembelajaran harus direfleksi, siswa diberi dasar untuk memperluas fokus, pembelajaran akan lebih baik jika dilakukan secara berkelompok dan berdiskusi sehingga akan tercipta pembelajaran yang menyenangkan dan berakibat kualitas pembelajaran dapat berhasil (Jayaseely, 2020).

\section{KESIMPULAN DAN SARAN}

Berdasarkan hasil dan pembahasan dapat disimpulkan bahwa proses berpikir spasial mahasiswa dengan kecerdasan intrapersonal tinggi dan sedang dapat menyelesaikan masalah geometri secara menyeluruh. Keempat subjek mencapai kelima indikator kemampuan spasial dengan benar, meskipun subjek dengan tipe sedang kurang sempurna pada indikator rotasi pikiran dan relasi keruangan. Semua subjek juga menggunakan seluruh unsur berpikir spasial dengan benar. Subjek hanya melakukan ketidaklengkapan pada unsur proses penalaran tetapi hasil akhir tetap benar.

Berdasarkan hasil temuan, dosen sebaiknya selalu mengontrol proses berpikir spasial, hal ini dimaksudkan untuk meminimalisir kesalahan mahasiswa dalam menyelesaikan masalah geometri. Untuk mewujudkan proses berpikir spasial yang benar dan lengkap, sebaiknya perlu dilakukan pendekatan pembelajaran yang berorientasi pada kecerdasan intrapersonal tinggi atau sedang. Penelitian ini terbatas pada subjek yang memiliki tipe kecerdasan intrapersonal tinggi dan sedang serta berpikir spasial dalam menyelesaikan masalah geometri. Dengan demikian masih sangat terbuka kesempatan untuk melakukan penelitian terkait berpikir spasial ditinjau dalam masalah lain, misalnya kecerdasan intrapersonal rendah, gaya kognitif, dan gaya belajar.

\section{DAFTAR PUSTAKA}

Abdi, A. W., \& Desfandi, M. (2020). Visual-spatial and intrapersonal intelligence: Identification its role in the learning outcomes of students in islamic schools. International Journal Pedagogy of Social Studies, 5(1), 112-121. https://doi.org/10.17509/ijposs.v5i 
DOI: https://doi.org/10.24127/ajpm.v10i2.3641

\subsection{9}

Ahamad, S. N. S. H., Li, H. C., Shahrill, M., \& Prahmana, R. C. I. (2018). Implementation of problem-based learning in geometry lessons. Journal of Physics: Conference Series, 943(1). https://doi.org/10.1088/17426596/943/1/012008

Behjat, F. (2012). Interpersonal and intrapersonal intelligences: Do they really work in foreign-language learning? Procedia - Social and Behavioral Sciences, 32(2010), 351355.

https://doi.org/10.1016/j.sbspro.2012 .01 .052

Bintoro, H. S., Zaenuri, \& Wardono. (2021). Application of information technology and communicationbased lesson study on mathematics problem-solving ability. Journal of Physics: Conference Series, 1918(4), 042105.

https://doi.org/10.1088/17426596/1918/4/042105

Bintoro, H. S., \& Zuliana, E. (2015). Penerapan interactive multimedia berbasis kurikulum 2013 ditinjau dari kecerdasan intrapersonal siswa pada pembelajaran matematika SD. Kreano, Jurnal Matematika KreatifInovatif, 6(2), 121. https://doi.org/10.15294/kreano.v6i2 .4683

Gleason, M. E. (2011). Intrapersonal intelligence strategies in the developmental writing classroom. Inquiry, 16(1), 95-105.

Hajhashemi, K., Caltabiano, N., Anderson, N., \& Tabibzadeh, S. A. (2018). Multiple intelligences, motivations and learning experience regarding video-assisted subjects in a rural university. International Journal of Instruction, 11(1), 167182.

https://doi.org/10.12973/iji.2018.111 $12 \mathrm{a}$
Jayaseely, M. (2020). Exploring the impact of multiple intelligence on interest among high school students. Journal of Critical Reviews, 7(4), 837-839. https://doi.org/10.31838/jcr.07.04.156

Khusna, A. H., \& Anissa, A. K. (2021). Pengembangan instrumen pembelajaran berdasarkan RECCEMODEL pada materi geometri transformasi. AKSIOMA: Jurnal Program Studi Pendidikan Matematika, 10(1), 443-456.

Kurniati, N. S., Supratman, S., \& Madawistama, S. T. (2021). Proses berpikir spasial peserta didik ditinjau dari gaya belajar. Journal of Authentic Research on Mathematics Education (JARME), 3(1), 22-33. https://doi.org/10.37058/jarme.v3i1. 1820

Mulbar, U., Arwadi, F., \& Assagaf, S. F. (2019). The influences of intrapersonal intelligence and interpersonal intelligence towards students' mathematics learning outcomes. Proceedings of the 1st International Conference on Advanced Multidisciplinary Research, 227(2019), 219-221. https://doi.org/10.2991/icamr18.2019 .54

Murni, S., \& Ruqoyyah, S. (2020). Development of teaching materials using a realistic mathematics education approach in a multiple intelligences perspective of elementary school students. PrimaryEdu - Journal of Primary Education, $\quad 4(2), \quad 208$. https://doi.org/10.22460/pej.v4i2.19 12

Murtafi'ah, W., \& Masfingatin, T. (2015). Proses berpikir mahasiswa dengan kemampuan spatial intellegent tinggi dalam memecahkan masalah geometri. Jurnal Ilmiah Pendidikan Matematika, 6(1), 133-148. 
DOI: https://doi.org/10.24127/ajpm.v10i2.3641

Perez, M. M. P., \& Ruz, N. R. (2014). Intrapersonal intelligence and motivation in foreign language learning. European Scientific Journal, 10(7), 142-150.

Permatasari, I., Pramudya, I., \& Kusmayadi, T. A. (2018). Spatial ability of slow learners based on Hubert Maier theory. Journal of Physics: Conference Series, 983(1). https://doi.org/10.1088/17426596/983/1/012095

Prisani, A. (2017). Teacher's Effort In Improving student intrapersonal intelligence through Student Facilitator And Explaining (SFAE) method in IPS Learning. International Journal Pedagogy of Social Studies, 2(1), 136. https://doi.org/10.17509/ijposs.v2i1. 8687

Seah, R. T. K., \& Horne, M. (2020). The influence of spatial reasoning on analysing about measurement situations. Mathematics Education Research Journal, 32(2), 365-386. https://doi.org/10.1007/s13394-02000327-w

Serin, H. (2018). Perspectives on the teaching of geometry: Teaching and learning methods. Journal of Education and Training, 5(1), 1. https://doi.org/10.5296/jet.v5i1.1211 5

Setyaningrum, F., \& Siswantari, H. (2020). Visual-Spatial and intrapersonal intelligence in learning of Rampak Kendang art for elementary school students. International Journal of Creative and Arts Studies, 7(1), 49-60. https://doi.org/10.24821/ijcas.v7i1.4 163

Sholikhati, R., Mardiyana, \& Sari Saputro, D. R. (2018). Students' thinking level based on intrapersonal intelligence. Journal of Physics: Conference Series, 943(1). https://doi.org/10.1088/1742-

6596/943/1/012007
Simpuruh, I. (2020). Improving the students' ability to write descriptive paragraph through intrapersonal intelligence strategy. ALGAZALI International Journal of Educational Research, 2(2), 114-121.

Sukestiyarno. (2020). Metode Penelitian Pendidikan. UNNES PRESS.

Tikhomirova, T. (2017). Spatial thinking and memory in russian high school students with different levels of mathematical fluency. Procedia Social and Behavioral Sciences, 237(2017), 1260-1264. https://doi.org/10.1016/j.sbspro.2017 .02 .204

Wicaksono, A. B., Chasanah, A. N., \& Sukoco, H. (2021). Kemampuan pemecahan masalah geometri berbasis budaya ditinjau dari gender dan gaya belajar. AKSIOMA: Jurnal Program Studi Pendidikan Matematika, 10(1), 240-251.

Zuliana, E., Oktavianti, I., Ratnasari, Y., \& Bintoro, H. S. (2020). Design and application of marionette tangram: an educational teaching media for mathematics and social science learning process in elementary schools. Universal Journal of Educational Research, 8(3), 931935.

https://doi.org/10.13189/ujer.2020.0 80326

Zuya, H. E., \& Kwalat, S. K. (2015). Teacher' $s$ knowledge of students a bout geometry. International Journal of Learning, Teaching and Educational Research, 13(3), 100114. 